\title{
Front Matter: Volume 10724
}

, "Front Matter: Volume 10724," Proc. SPIE 10724, Physical Chemistry of Semiconductor Materials and Interfaces XVII, 1072401 (15 October 2018); doi: $10.1117 / 12.2515894$

SPIE Event: SPIE Nanoscience + Engineering, 2018, San Diego, California, United SPIE. States 


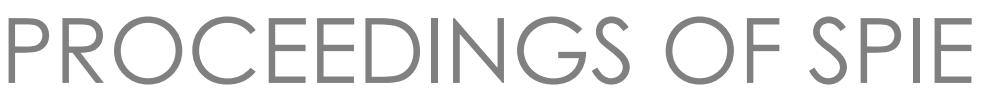

\section{Physical Chemistry of Semiconductor Materials and Interfaces XVII}

Hugo A. Bronstein

Felix Deschler

Thomas Kirchartz

Editors

20-23 August 2018

San Diego, California, United States

Sponsored and Published by

SPIE 
The papers in this volume were part of the technical conference cited on the cover and title page. Papers were selected and subject to review by the editors and conference program committee. Some conference presentations may not be available for publication. Additional papers and presentation recordings may be available online in the SPIE Digital Library at SPIEDigitallibrary.org.

The papers reflect the work and thoughts of the authors and are published herein as submitted. The publisher is not responsible for the validity of the information or for any outcomes resulting from reliance thereon.

Please use the following format to cite material from these proceedings:

Author(s), "Title of Paper," in Physical Chemistry of Semiconductor Materials and Interfaces XVII, edited by Hugo A. Bronstein, Felix Deschler, Thomas Kirchartz, Proceedings of SPIE Vol. 10724 (SPIE, Bellingham, WA, 2018) Seven-digit Article CID Number.

ISSN: 0277-786X

ISSN: 1996-756X (electronic)

ISBN: 9781510620193

ISBN: 9781510620209 (electronic)

Published by

SPIE

P.O. Box 10, Bellingham, Washington 98227-0010 USA

Telephone +1 3606763290 (Pacific Time) · Fax +1 3606471445

SPIE.org

Copyright @ 2018, Society of Photo-Optical Instrumentation Engineers.

Copying of material in this book for internal or personal use, or for the internal or personal use of specific clients, beyond the fair use provisions granted by the U.S. Copyright Law is authorized by SPIE subject to payment of copying fees. The Transactional Reporting Service base fee for this volume is $\$ 18.00$ per article (or portion thereof), which should be paid directly to the Copyright Clearance Center (CCC), 222 Rosewood Drive, Danvers, MA 01923. Payment may also be made electronically through CCC Online at copyright.com. Other copying for republication, resale, advertising or promotion, or any form of systematic or multiple reproduction of any material in this book is prohibited except with permission in writing from the publisher. The CCC fee code is 0277 $786 \mathrm{X} / 18 / \$ 18.00$.

Printed in the United States of America.

Publication of record for individual papers is online in the SPIE Digital Library.

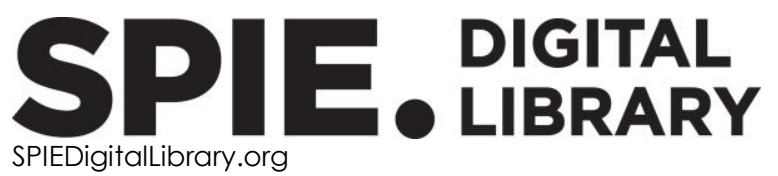

Paper Numbering: Proceedings of SPIE follow an e-First publication model. A unique citation identifier (CID) number is assigned to each article at the time of publication. Utilization of CIDs allows articles to be fully citable as soon as they are published online, and connects the same identifier to all online and print versions of the publication. SPIE uses a seven-digit CID article numbering system structured as follows:

- The first five digits correspond to the SPIE volume number.

- The last two digits indicate publication order within the volume using a Base 36 numbering system employing both numerals and letters. These two-number sets start with 00, 01, 02, 03, 04, $05,06,07,08,09,0 A, 0 B \ldots$. OZ, followed by 10-1Z, 20-2Z, etc. The CID Number appears on each page of the manuscript. 


\title{
Contents
}

\author{
$\checkmark \quad$ Authors \\ vii Conference Committee
}

PHYSICAL CHEMISTRY OF SEMICONDUCTOR MATERIALS AND INTERFACES AND ORGANIC, HYBRID, AND PEROVSKITE PVS: JOINT SESSION WITH CONFERENCES 10724 AND 10737

1072403 Composition of molecular aggregates during film formation revealed using simulated absorption spectra (Invited Paper) [10724-2]

PHYSICS OF HALIDE PEROVSKITE SOLAR CELLS

$1072408 \quad$ XPS depth profiles of organo lead halide layers and full perovskite solar cells by variable-size argon clusters [10724-7]

10724 OA Development of a novel mixed sulfide-iodide lead-free bismuth perovskite [10724-59]

\section{SPECTROSCOPY OF PEROVSKITE FILMS AND DEVICES}

10724 OF Probing the photophysics of semiconductor nanomaterials using optical pump-terahertz probe spectroscopy: from nanowires to perovskites (Invited Paper) [10724-13]

LOWER DIMENSIONAL MATERIALS

1072412 Effects of local environment on the ultra-fast carrier dynamics of photo-excited 2D transition metal dichalcogenides [10724-35]

1072413 Integrating plasmonic metals and 2D transition metal dichalcogenides for enhanced nonlinear frequency conversion [10724-36]

\section{NANOSTRUCTURES}

10724 IC Fabrication of high quantum yield of CIS/ZnS quantum dots [10724-45]

10724 ID Ultrafast revealing of invisible patterns encrypted in colloidal photonic crystals [10724-46] 
Proc. of SPIE Vol. 10724 1072401-4 Downloaded From: https://www.spiedigitallibrary.org/conference-proceedings-of-spie on 26 Apr 2023
Terms of Use: https://www.spiedigitallibrary.org/terms-of-use 


\section{Authors}

Numbers in the index correspond to the last two digits of the seven-digit citation identifier (CID) article numbering system used in Proceedings of SPIE. The first five digits reflect the volume number. Base 36 numbering is employed for the last two digits and indicates the order of articles within the volume. Numbers start with 00, 01, 02, 03, 04, 05, 06, 07, 08, 09, OA, OB...0Z, followed by 10-1Z, 20-2Z, etc.

Adeyemo, Stephanie O., OF

Agresti, Antonio, 08

Baig, Sarwat A., OF

Benamara, Mourad, 13

Boland, Jessica L., OF

Bonacina, Luigi, 13

Busby, Yan, 08

Chang, C. W., IC

Chung, S. R., 1C

Clays, Koen, ID

Davies, Christopher L., OF

Deschler, Felix, OF

Di Carlo, Aldo, 08

Dunklin, Jeremy R., 12, 13

Eyre, Lissa, OF

Forcherio, Gregory T., 13

Gao, Liguo, OA

Houssiau, Laurent, 08

Jagadish, C., OF

Johnston, Michael B., OF

Joyce, Hannah J., OF

Kamata, Yusuke, OA

Le Dantec, R., 13

Ma, Tingli, OA

Miller, Elisa M., 12

Mugnier, Yannick, 13

Noël, Celine, 08

Pandit, Rima B., 03

Pescetelli, Sara, 08

Pireaux, Jean-Jacques, 08

Riporto, Jérémy, 13

Roper, D. Keith, 13

Song, Kai, ID

Sosa, Morgan L., 03

Tan, H. Hoe, OF

Teo, Siohwa, OA

van de Lagemaat, Jao, 12

Wang, K. W., 1C

Wilson, Kelly S., 03

Wong, Cathy Y., 03

Zhang, Chu, OA

Zhang, Hanyu, 12

Zhong, Kuo, 1D 
Proc. of SPIE Vol. 10724 1072401-6

Downloaded From: https://www.spiedigitallibrary.org/conference-proceedings-of-spie on 26 Apr 2023 Terms of Use: https://www.spiedigitallibrary.org/terms-of-use 


\title{
Conference Committee
}

\author{
Symposium Chairs
}

Halina Rubinsztein-Dunlop, The University of Queensland (Australia)

Mark L. Brongersma, Geballe Laboratory for Advanced Materials

(GLAM), Stanford University (United States)

Symposium Co-chairs

Harry A. Atwater Jr., California Institute of Technology (United States)

Nikolay I. Zheludev, Optoelectronics Research Centre

(United Kingdom) and Nanyang Technological University

(Singapore)

Conference Chairs

Hugo A. Bronstein, University College London (United Kingdom)

Felix Deschler, University of Cambridge (United Kingdom)

Conference Co-chair

Thomas Kirchartz, Forschungszentrum Jülich GmbH (Germany)

Conference Program Committee

John B. Asbury, The Pennsylvania State University (United States)

Artem A. Bakulin, Imperial College London (United Kingdom)

Jenny Clark, The University of Sheffield (United Kingdom)

Gitti Frey, Technion-Israel Institute of Technology (Israel)

Alexandre Fürstenberg, Université de Genève (Switzerland)

David S. Ginger, University of Washington (United States)

Robert Lovrincic, Technische Universität Braunschweig (Germany)

Naomi S. Ginsberg, University of California, Berkeley (United States)

Jeanne L. McHale, Washington State University (United States)

Paul Meredith, The University of Queensland (Australia)

Linda A. Peteanu, Carnegie Mellon University (United States)

Carlos Silva, Georgia Tech Research Institute (Canada)

Sergei Tretiak, Los Alamos National Laboratory (United States)

Lauren Webb, The University of Texas at Austin (United States) 


\section{Session Chairs}

1 Physical Chemistry of Semiconductor Materials and Interfaces and Organic, Hybrid, and Perovskite PVs: Joint Session with Conferences 10724 and 10737

Hugo A. Bronstein, University of Cambridge (United Kingdom)

Paul A. Lane, NSF (Professional Development) (United States)

2 Physics of Halide Perovskite Solar Cells

Felix Deschler, University of Cambridge (United Kingdom)

3 Light-Emitting Devices Based on Perovskites

Bruno Ehrler, AMOLF (Netherlands)

4 Spectroscopy of Perovskite Films and Devices

Kimberley C. Hall, Dalhousie University (Canada)

5 Lower-Dimensional Perovskites and Nanocrystals

Hemamala Karunadasa, Stanford University (United States)

6 Organic Photovoltaics

Hugo A. Bronstein, University of Cambridge (United Kingdom)

7 Fundamentals of Organic Semiconductors

Andrew J. Musser, The University of Sheffield (United Kingdom)

8 Excitons in Organic Semiconductors

Leeor Kronik, Weizmann Institute of Science (Israel)

9 Functional Organic Materials

Sean Roberts, The University of Texas at Austin (United States)

10 Lower Dimensional Materials

Linda A. Peteanu, Carnegie Mellon University (United States)

11 Surfaces and Interfaces

Kenan Gundogdu, North Carolina State University (United States)

12 Nanostructures

Norbert Koch, Humboldt-Universität zu Berlin (Germany) 